\section{SMGrøup}

\section{SM Journal of Nephrology and Kidney Diseases}

\author{
Article Information \\ Received date: Oct 02, 2017 \\ Accepted date: Oct 13, 2017 \\ Published date: Oct 20, 2017 \\ ${ }^{*}$ Corresponding author
}

Can Hüzmeli, Necip Fazil City Hospital, Nephrology Clinic, Kahramanmaraş,

Turkey, Tel: 90-5067159443;

Email: chuzmeli@hotmail.com

Distributed under Creative Commons CC-BY 4.0

Article DOI 10.36876/smjnkd.1006

\title{
Pseudohypercreatininemia after Sustanon Injection
}

\author{
Can Hüzmeli ${ }^{1}$, Mustafa Sağlam ${ }^{1}$, Bariş Döner ${ }^{1}$, Serkan Çağlar ${ }^{2}$ and Özkan \\ Güngör ${ }^{3}$ \\ 'Necip Fazil City Hospital, Nephrology Clinic, Turkey \\ 'Department of Biochemistry, Necip Fazil City Hospital, Turkey \\ 'Department of Nephrology, Sütçü İmam University, Turkey
}

\section{Abstract}

The drugs used in the treatment of certain diseases may give impression of impaired renal function These drugs cause a false high serum creatinine level. Laboratory findings other than serum creatinine and hypertriglyceridemia were normal. We presented a 28 -year-old male with a high serum creatinine level, who was referred for consideration of urgent renal replacement therapy. The results of the investigations revealed that the result was the falsely-elevated serum creatinine due to the sustenance injection.

\section{Introduction}

Serum creatinine is one of the most commonly used biochemical parameters in the diagnosis of kidney diseases. Creatinine is non-enzymatically generated from creatine phosphate at a constant rate in all the muscle cells of the body and creatinine is excreted in the urine as $20-26 \mathrm{mg} / \mathrm{kg} /$ day in males and $14-22 \mathrm{mg} / \mathrm{kg} /$ day in females. Serum creatinine values are affected by age, gender, exercise, muscle mass, some drugs and nutrient intake. In addition, serum creatinine is affected by tubular secretion, and the analytical interferences and uncertainties in calibration that occur during measurement are a major problem. Serum creatinine values remain within the reference range until significant loss of renal function [1-3]. The purpose of this case is to emphasize the high serum pseudohypercreatininemia.

Case

A 28-year-old male patient who had been diagnosed with hypogonadism a week ago started on a sustanon (Testosterone Propionate + Testosterone Phenylpropionate) amp. One day after the injection of Sustanon, he was referred to my hospital because of the weakness and dizziness and the serum creatinine was $6.5 \mathrm{mg} / \mathrm{dl}$ in the tests of the patient who applied to the Internal Medicine polyclinic. Patients had diabetes mellitus (using metformin in treatment) and hypertriglyceridemia (the fenofibrate treatment was discontinued 6 months ago) in his biography. Weakness and dizziness were thought to be due to hypertriglyceridaemia. On physical examination, blood pressure was 120 / $80 \mathrm{mmHg}$, pulse was 74 / min and systemic physical examination was normal. Laboratory tests serum creatinine $11 \mathrm{mg} / \mathrm{dL}$, blood urea nitrogen was $20 \mathrm{mg} / \mathrm{dl}$ total protein and albumin were normal triglyceride was measured as $1181 \mathrm{mg} / \mathrm{dl}$. In complete urine analysis, microalbuminuria and proteinuria were not detected. The renal ultrasonography performed was evaluated as normal. When we questioned the patient, he said that he had a sustenon amp two days ago before applying to our clinic. Serum creatinine was calculated as $0.8 \mathrm{mg} / \mathrm{dl}$ when the patient's serum creatinine was make centrifugal at $15000 \mathrm{rpm}$ for 30 minutes and the serum clear fraction was taken and studied by the Jaffe method. In addition, serum creatinine levels at 5 th day and at one month later were within normal limits (old method is used) but serum triglyceride levels was higher because they did not use antihyperlipidemic drugs.

\section{Discussion}

Serum creatinine levels commonly used in acute renal disease and chronic renal disease are measured by several analytical methods. Serum creatinine level is influenced by analysis methods. Both Jaffe method and enzymatic analysis method, which are the most common measurement methods of serum creatinine, are affected by drugs. Besides, some drugs cause false high serum creatinine levels. In addition, serum creatinine production, distribution and tubular secretion are affected by certain drugs.

The Jaffe method is the most widely used and calorimetric test for serum creatinine. Since the Jaffe method is a calorimetric test, some substances in the plasma and serum may cause a color change similar to that of serum creatinine, resulting in an erroneous detection of serum creatinine. Acetone and acetoacetate (such as diabetic ketoacidosis), endogenous substances such as fasting, hyperlipemia,

\section{OPEN ACCESS


haemolysis and drugs such as antibiotics, especially cephalosporins (cefoxitin, cefazolin), $\mathrm{N}$-acetyl cysteine, dexamethasone, barbiturates (such as valproic acid), and chemotherapeutics may cause jaffe to cause an incorrectly high assessment of serum creatinine. One of the serum creatinine measurement methods is the enzymatic (known as the Ektachem method) method. This method is influenced by certain drugs such as flucytosine [4-10]. Hummel and colleagues found pseudohypercreatininemia in 3 cases of Waldenström's macroglobulinemia. Serine creatinine levels were $5.4 \mathrm{mg} / \mathrm{dL}, 3.3$ $\mathrm{mg} / \mathrm{dL}$ and $4.0 \mathrm{mg} / \mathrm{dL}$, respectively, when measured by routine enzymatic testing. Serum creatinine values after enzymatic filtration were respectively $0.8 \mathrm{mg} / \mathrm{dL}, 1.1 \mathrm{mg} / \mathrm{dL}$ and $0.7 \mathrm{mg} / \mathrm{dL}$. In addition, serum creatinine levels were determined as $0.8 \mathrm{mg} / \mathrm{dL}, 1.0 \mathrm{mg} / \mathrm{dL}$ and $0.6 \mathrm{mg} / \mathrm{dL}$, respectively, by HPLC method. It is emphasized that this erroneously high measurement is due to the height of monoclonal $\operatorname{IgM}[11]$.

As a conclusion, some drugs and diseases lead to a false high serum creatinine value. In such cases, more precise testing is needed. Other findings indicating renal impairment are normal, but the height of serum creatinine should be considered as the height of false serum creatinine. In such cases, more precise testing is needed.

\section{References}

1. Kurtal H, Schwenger V, Azzaro M, Abdollahnia N, Steinhagen-Thiessen E, Nieczaj R, et al. Clinical value of automatic reporting of estimated glomerular filtration rate in geriatrics. Gerontology. 2009; 55: 288-95.

2. Poggio ED, Wang X, Greene T, Van Lente F, Hall PM. Performance of the modification of diet in renal disease and Cockcoft-Gault equations in the estimation of GFH in health and in chronic kidney disease. J Am Soc Nephrol. 2005; 16:459-466.
3. Swedko PJ, Clark HD, Paramsothy K, Akbari A. Serum creatinine is an inadequate screening test for renal failure in elderly patients. Arch Intern Med. 2003; 163: 356-360.

4. Molitch ME, Rodman E, Hirsch CA, Dubinsky E. Spurious serum creatinine elevations in ketoacidosis. Ann Intern Med. 1980; 93: 280-281.

5. Samara M, Abcar AC. False estimates of elevated creatinine. Perm J. 2012; 16: $51-52$.

6. Saah AJ, Koch TR, Drusano GL. Cefoxitin falsely elevates creatinine levels. JAMA. 1982; 247: 205-206.

7. Smith $\mathrm{CH}$, Landt $\mathrm{M}$, Steelman M, Ladenson JH. The Kodak Ektachem 400 Analyzer evaluated for automated enzymic determination of plasma creatinine. Clin Chem. 1983; 29: 1422-1425

8. Makiishi T, Yamamoto S, Maeda S. Case of suspected pseudo-elevation of serum creatinine immediately after intra-articular injection into a wrist joint of a pharmaceutical preparation of dexamethasone containing creatinine as a buffer. Nihon Jinzo Gakkai Shi. 2011; 53: 200-206.

9. Mitchell RT, Marshall LH, Lefkowitz LB Jr, Stratton CW. Falsely elevated serum creatinine levels secondary to the presence of 5-fluorocytosine. Am J Clin Pathol. 1985; 84: 251-253.

10. Fukazawa H. Valproic acid induced pseudohypercreatininemia. No to Hattatsu. 1990; 22: 86-87

11. Hummel KM, von Ahsen N, Kühn RB, Kaboth U, Grunewald RW, Oellerich M, et al. Pseudohypercreatininemia due to Positive Interference in Enzymatic Creatinine Measurements Caused by Monoclonal IgM in Patients with Waldenström's Macroglobulinemia. Nephron. 2000; 86: 188-189. 